\title{
Performatyvūs veikèjų tinklai Gintauto Trimako kūriniuose
}

\section{Marius Armonas}

Lietuvos kultūros tyrimų institutas

Saltoniškių g. 58, LT-08105 Vilnius

armonas.m@gmail.com

— Straipsnyje remiamasi nuostata, kad kūrinys neturètų būti traktuojamas tik kaip semantinis ženklas, atstovaujantis kažkam kitam, esančiam už savo paties ribų, ir jị referuojantis, todèl ši kartą susitelkta ị materialiojo fotografijos performatyvumo aspektus. Svarstomos fotografijos ir instaliacijos meno sąveikos, nagrinëjama, kaip ịvairūs erdvès ir aplinkos objektai gali prisidèti prie kūrinio atlikimo. Keliama hipotezè, kad ìvairiu objektų sąveika leidžia fotografijai igauti papildomus performatyvumo sluoksnius ir išjudinti gamtos-kultūros, objekto-subjekto dichotomijas. Nors išplèsta, įerdvinta fotografija nèra nauja strategija, šiuolaikiniame mene vykstanti disciplininių ribų entropija tampa akstinu apžvelgti vis naujas jų konfigūracijas. Šị kartą tai atliekama analizuojant fotomenininko Gintauto Trimako parodą Atsakymas.

Reikšminiai žodžiai: fotografija, instaliacija, tinklaveika, performatyvumas, posthumanizmas. 
Fotomenininko Gintauto Trimako kūryba pasižymi įvairiais fotografiniais eksperimentais, bandymais šiuolaikiniame meno lauke aktualizuoti senus fotografinius metodus ir priemones. Tai liudija menininko projektai, kaip kad 2007 m. pradètas fotografiju ciklas Miestas kitaip, kuris buvo atliktas prie dviračio pritvirtinus kamerą ir ịvairiose miestų vietose fotografuojant atsitiktinius vaizdus. Autorius tuomet teigè sąmoningai rinkęsis atsitiktinumą ir apsisprendimą ,nematyti“ to, ką fotografuoja ${ }^{1}$. Komentuodamas ši projektą yra sakęs: „Esu tik koncepcijos autorius, o fotografuoja dviratis - prie jo bagažinės pritvirtinu pinhole kamerą, kuri fiksuoja tai, ką „mato““'2. Toks menininko teiginys itin intriguojančiai ir aktualiai nuskamba šiuolaikinèje filosofijoje aktyviai plètojamų posthumanizmo idejjų šviesoje, kuriose kalbama apie etinę rekonfigūraciją, kai kvestionuojama antropocentrinio mąstymo įtvirtinta skirtis tarp subjekto ir objekto.

Nors šis projektas vèliau nebuvo tęsiamas, paskutinị dešimtmetị ivvairiuose akademiniuose, publicistiniuose ir reprezentaciniuose tekstuose apie menines G. Trimako praktikas galima matyti panašaus pobūdžio įtampas tarp objekto, jo paviršiaus ir erdvės ${ }^{3}$ konkretybės ir abstrakcijos ${ }^{4}$, laiko, jo tęstinumo ir belaikiškumo 5 . Visi šie elementai byloja jo fotografijas esant daugiau nei fotografiniu atvaizdu, fiksuojančiu ir reprezentuojančiu tam tikrus vaizdus. Tai gan tiksliai apibūdina Alvydas Lukys: „paveikslinis-kosminis Trimako erdvėlaikis yra gryna užkoduota energija“"6. Tokie ne iki galo aiškūs ir kartkartėmis poetiškai mistifikuojami G. Trimako kūrybos principai šiame straipsnyje yra priimami kaip signalai, rodantys poreiki i šio fotografo darbus pažvelgti iš nauju pozicijų. Todèl šiame straipsnyje bandoma apsvarstyti, koks gali būti minètų erdvių, laikų ir energijų indèlis ị jo kūrinius. Atsižvelgimas ị šių veikèju ittaką kūrybiniams procesams gali būti suprantamas kaip etinis veiksmas, kuris pats savaime leidžia pergalvoti kūrybini procesą, rezultatą bei techninius ir konceptualius jo pagrindus. Galiausiai, bandymas atkreipti dèmesị i nežmogiškųjų veikejjų

1 Gintautas Trimakas, „Apie miestą kitaip“, in: Idem, Miestas kitaip = City. A Different Angle. Vilnius \} Köln \} Klaipéda \} Lviv \}, sud. Margarita Matulyte, Kaunas: Kitos knygos, 2009.

2 Ibid.

3 Jonas Valatkevičius, „Trimakas. Ten ir čia. Dabar ir kažkada“, in: \{Gintautas\} Trimakas, Miestas kitaip, puslapiai nenurodyti.

4 Agnè Narušytè, „Fotografijos fenomenologija pagal Gintautą Trimaką“, in: Gintautas Trimakas, [fotografijų albumas], sud. Gytis Skudžinskas, Gintautas Trimakas, Agnė Narušytè, Vilnius: Lietuvos fotomenininkų sajungos fotografijos fondas, 2016, p. 17.

5 Alvydas Lukys, „Dabartis tęsiasi: Gintauto Trimako Fotokosmosas“, in: ibid., p. 184.

6 Ibid., p. 185. 
indèli i menininko kūrybą atveria galimybę ịsitraukti ị posthumanistinių idejų svarstymo lauką, kuris atrodo itin artimas ir aktualus jo kūrybos principams, tačiau ryškesnių siekių tai padaryti iki šiol nebuvo, todèl tikimasi, kad ši analizè taip pat pasitarnaus kaip žingsnis, aktualizuojantis G. Trimako darbus šiuolaikinės filosofijos ir meno idejjų kontekste.

\section{Gintauto Trimako camera-less fotografija}

G. Trimakas jau daugeli metų užsiima fotografinių procesų tyrimais ir eksperimentais, garsėja gebejjimu naudotis ir šiuolaikiniame mene konceptualiai išnaudoti senąsias fotografines technikas. Pastaraisiais metais grupinėse ir personalinėse parodose menininkas vis rečiau pristatinejjo naujus kūrinius, kuriuose būtų galima pamatyti tradicinius fotografinius vaizdus, o parodų anotacijose vis dažniau teko ir tenka girdèti apie spalvos paieškas ir šviesos fiksavimą - tai esminiai principai jo kuriamose cameraless fotografijose. Šiam fotografiniam metodui priskiriamos iqvairios fotografinio vaizdo kūrimo technikos, kurioms atlikti nereikalingas fotoaparatas, bet pasitelkiama šviesai jautrus popierius ir ịvairūs cheminiai junginiai. Anot G. Trimako, šis fotografinis metodas po ilgų paieškų jam tapo tinkamiausia technika, o kūrybos procesą menininkas ịvardija kaip „„̌aidybiškai performatyvų veiksmą"7.

Siekiant analizuoti G. Trimako kuriamas camera-less fotografijas šiam straipsniui pasirinktas vienas jo kūrybos ir ekspozicijos fragmentas 2018 m. rudeni galerijoje „Vartai“ (Vilnius) surengta personalinė paroda Atsakymas, kurios ekspozicijoje buvo ịvairių formatų camera-less fotografijų serijos. Šis atvejis pasirinktas dèl kelių esminių priežasčių: tai viena didžiausiu jo surengtų personaliniu parodų pastaraisiais metais, joje buvo išskleista gana plati menininko kūrybos amplitudè, atspindinti naujausias jo kūrybos tendencijas, ir galiausiai, konkretaus parodos atvejo analizè leidžia jungti G. Trimako kūrinius su ekspozicine erdve ir ją laikyti integralia kūrinio dalimi, viena vykstančia situacija. Būtent procesualumas ir sąveika su erdve igauna svarbą atsižvelgiant ị tai, kad šioje parodoje menininkas eksponavo ne tik jau užbaigtus darbus, bet buvo parengęs ir kūrinius, kurių fotografiniai procesai vyko penkias savaites - visą parodos veikimo laiką ir

7 Gintautas Trimakas, „Lumen: Parodos anotacija“, [interaktyvus], in: artnews internetinė svetainè, [žiūrèta 2020-08-22], https://artnews.lt/gintauto-trimako-paroda-lumen-galerijoje-menoparkas-diuseldorfe-56360. 


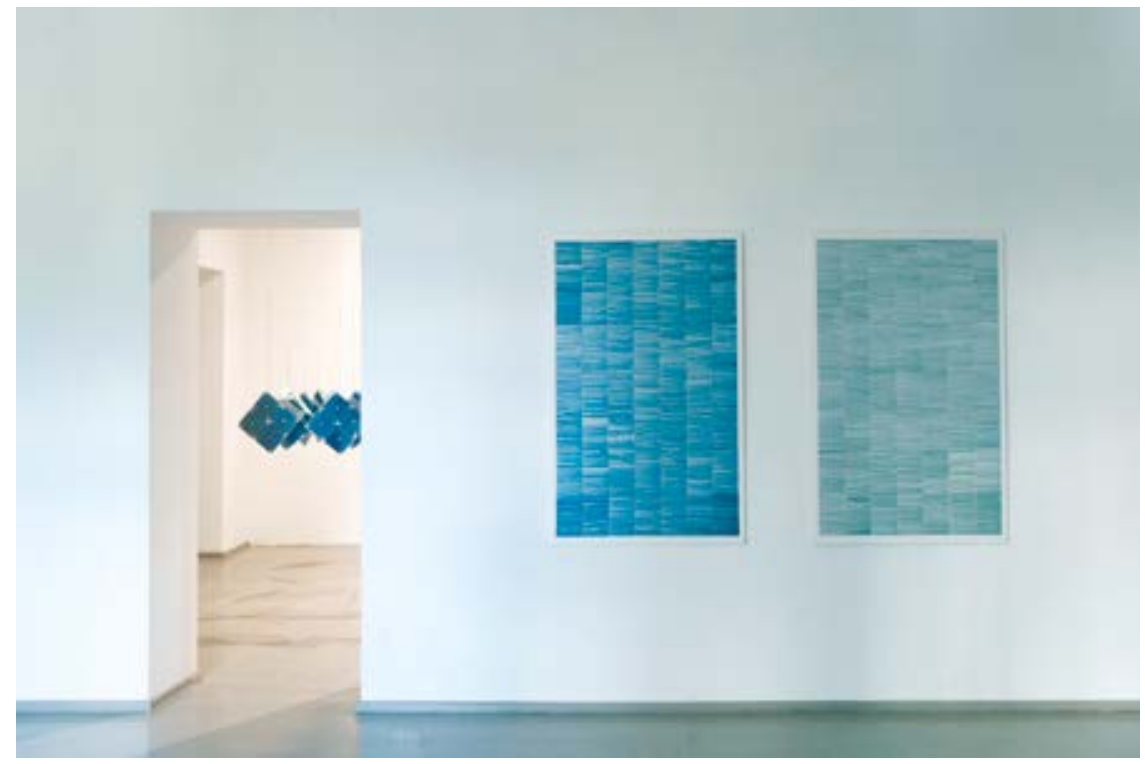

1.

lėmė ekspozicijos pokyčius. Šis veiksnys tapo vienu iš pagrindinių akstinų šiai analizei ir paskatino ekspozicijos dalis nagrinèti kaip instaliacijos meną, kuriame ị performatyvų tinklą jungiasi visi aplinkos veikejjai [1 il.].

I G. Trimako kūrinius šioje analizèje siūloma žiūrèti kaip ị instaliacijos objektus. Toks judesys kūrinius ir jų serijas leidžia apsvarstyti ne tik kaip atskirus objektus, veikiančius dualistinėje subjekto-objekto struktūroje, bet aktyvuoti ir aplinkos veiksnius - ịtraukti ekspozicinę erdvę, joje esančius elementus ir aplinkoje vykstančius procesus. Tokị poreikị išryškina minèti kitų autorių teiginiai apie fotografo kūrinių tąsumą laike ir erdvèje. Toki poreiki pagrindžia ir A. Narušytès komentaras: ,jo kūriniai dažniausiai peržengia vaizdo ribas, itraukdami erdvę, muziką, kultūrinę aplinką

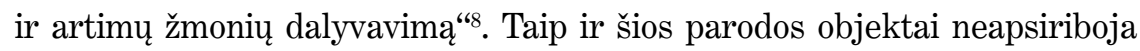
fotografinio vaizdo paviršiumi, jo perimetru - pasitelktus fotografinius procesus šviesa ji sujungia su aplinka, tapusia viena iš kūrinio atlikẻjų. 
Šiuolaikinį instaliacijos meną galima įvardyti kaip vieną iš takiausių meno rūšių, kurios pavadinimas savaime rodo dvilypi procesą - instaliaciją kaip kūrinių eksponavimą ir kaip sąlygiškai baigtinį, kompleksišką erdvinį kūrinị. Žodis „instaliacija“ dabar yra išsiskleidęs tiek, kad juo galima apibūdinti bet kokị objektų išdėstymą bet kokioje erdvẻje net iki taško, kai jis gali būti taikomas net ịprasčiausiam tapybos darbų eksponavimui ant sienos. Mišrių technikų ir medžiagų naudojimas bei dinamiškas santykis su erdve ir žiūrovu jai leido tapti itin pažangiu meninès raiškos būdu.

Tai išryškina vieno žinomiausių šių laikų meno kritikų Halo Fosterio teiginys, kad nuo „specifinès medijos“ instaliacija perèjo prie „specifinès diskusijos“ - tokios meno formos, kurią apibrèžia ne kokia nors tradicinė meno raiška, o tai, kokią žinutę ji perduoda, kad ir kokiomis priemonėmis tai būtų atliekama ${ }^{9}$. Todèl ši meno rūšis itin sẻkmingai prisitaikè šiuolaikinio meno lauke ir yra plačiai taikoma meno praktika, tai rodo ir meno tyrejjo Jonathano Crary teiginys, kad XX a. 10-ajame dešimtmetyje instaliacijos menas iš gana marginalios meno praktikos tapo viena svarbiausių šiuolaikinio meno rūšių ${ }^{10}$.

Šiandien instaliacija yra dažnai naudojama, ją galima ịvardyti kaip mediatorių, kuris dèl savo lankstumo po savo meno kategorijos skèčiu gali priimti kitas meno praktikas. Instaliacijos menas suteikia galimybę ịvairioms hibridinėms meno praktikoms įsitvirtinti šiuolaikinio meno lauke. Instaliacijose pastebimą įvairių meno disciplinų susipynimą galima ịvardyti per pastaruosius tris dešimtmečius itin paplitusiu hibrido terminu. Jis dažniausiai siejamas su prancūzų sociologu ir filosofu Bruno Latouru, kurio knyga Mes niekada nebuvome modernūs tapo vienu iš kertinių šaltinių, siejamų su gamtos ir kultūros dichotomijos persvarstymu, ir yra iggavęs dideli atgarsị ne tik teoretikų diskusijose, bet ir šiuolaikinio meno praktikose.

\section{Tinklaveika ir performatyvumas}

B. Latouras pasiūlè tinklaveikos teoriją, kurioje panaikinama tradicinė subjekto-objekto gamtos ir kultūros dialektika, o daiktai ir žmonės joje tampa mediatoriu grandinėmis, heterogeniškais elementais, iš kurių

9 Hal Foster, „The Un/making of Sculpture“, in: Richard Serra: Sculpture 1985-98, sud. Ferguson et al., Gottingen and Los Angeles, 1998, p. 36.

10 Nicolas de Oliveira, Nicola Oxley, Michael Petry, Installation Art in the New Millennium, London: Thames and Hudson, 2003, p. 13. 
susidaro tarpusavio tinklai ${ }^{11}$. Tinklaveikos teorijos tikslas - atverti abstrakčiomis duotybėmis virtusias galios struktūras, parodyti, kaip ịvairių veikèju santykiai kuria tiesą ir galią. Tad ši teorija siūlo ị daiktus, žmones, procesus ir jų tarpusavio sąveikas žiūrèti ne kaip ị tam tikrus baigtinius ryšius, bet kaip ị vis naujus hibridinius darinius, kurių reikšmès ir galios nėra stabilios, bet kintančios - priklauso nuo kitų veikèjų. Šio mokslinio metodo uždavinys yra ne atsakyti ị klausimą, kodèl susidaro šie tinklai, bet juos - ryšius tarp žmonių ir daiktų - nužymèti ir tirti.

Tinklaveikos teorija yra reliacinė ir procesuali, veikèjus, organizacijas, prietaisus ir pan. reginti kaip sąveikaujančius veiksnumus, vienas kitą veikiančius gamtinius, socialinius ar politinius hibridus. B. Latouro teigimu, tinklai - arba, kitaip tariant, hibridiniai būviai - susieja ịvairias sritis ị neišpainiojamas sąveikas ir yra daugialypiai konglomeratai, realūs kaip gamta, naratyviniai kaip diskursas, kolektyviniai kaip visuomené ${ }^{12}$. Jo teorija skatina neatskirti mokslo, kultūros, gamtos ir daugybès kitų disciplinų, atvirkščiai - î juos žvelgti kaip ị kompleksiškus ir vienas kitą veikiančius hibridus.

B. Latouro išplètota idejja glaudžiai siejasi su filosofijoje, kaip ir mene, per dešimtą dešimtmeti įsitvirtinusiomis posthumanizmo teorijomis, kurias daugeliu atvejų, jungia pagrindinis antropocentrizmo kritikos projektas ir įvairūs bandymai nuvainikuoti žmogų, kaip aukščiau visų kitų rūšių esančią būtybę. Dèl to imama aktyviai svarstyti ne tik apie žmogaus kategoriją, bet îtraukiami ir nežmogiški esiniai - atsižvelgiama ì gyvūnų, augalų, technologijų ittakas, svarstomi ekologijos, klimato klausimai ir kiti Žemės planetoje ar mums žinomoje visatoje vykstantys procesai bei reiškiniai. Kaip teigia filosofė Audronè Žukauskaitė:

žmogus nėra išskirtinė gyvybės forma, esanti pačioje gyvybės formų hierarchijos viršūnėje; priešingai, žmogus turi suvokti, jog jis ne tik yra susijęs su kitomis gyvybės formomis, bet netgi yra nuo jų (pavyzdžiui, bakterijų) visiškai priklausomas. ${ }^{13}$

O ir materija, priešingai nei dominuojančioje Vakarų filosofijoje, nebėra laikoma pasyvia ir neturinčia reikšmès. Su posthumanizmu siejamų

11 Bruno Latour, Reassembling the Social: An Introduction to Actor-Network-Theory, Oxford: Oxford University Press, 2007, p. 39.

12 Bruno Latour, Mes niekada nebuvome modernūs, Vilnius: Homo liber, 2004, p. 13.

13 Audronė Žukauskaitè, „Pratarmë“, in: Athena, 2019, Nr. 14, p. 8-9. 
filosofų Bruno Latouro ar Donnos Haraway, Rosi Braidotti, Quentino Meillassoux, Grahamo Harmano, Jane Bennet ir kitų autorių tekstuose nuolat pabrèžiamas materijos „gyvumas“, „gyvybingumas“, „virpëjimas“, „veiksnumas“ ar „veikẻjiškumas“ taip bandant pastebèti ir ịvardyti materijos aktyvumo galimybes. Šias idèjas filosofai ịgyvendina skirtingais būdais, todèl ir posthumanizmą reikètų laikyti skètiniu terminu, kuriuo jungiamos įvairios ir nevienalytės filosofinès konstrukcijos, siūlančios alternatyvas antropocentriniam mąstymui.

Kitiems autoriams nuolat išryškinant G. Trimako kūrinių savarankiškumą ir eksperimentinị autoriaus požiūrị i kūrybos procesą, kai jis pats pripažįsta dažnai nežinantis, koks bus galutinis vizualinis tam tikro kūrinio rezultatas, iškyla meno kūrinių sąveikos su autoriumi ir aplinka klausimas. Toks menininko kūrybos principas atrodo artimas sociologo, filosofo Zygmunto Baumano pastebètam kismui nuo idealistinès modernaus meno sistemos, kurioje kūrybos siekis buvo užvaldyti, nugalèti medžiagą. Ją pakeitė materialistinè sistema, šios tikslas yra „leisti medžiagai kalbėti“"14. Tad atsižvelgiant i materialiuosius elementus, šiame straipsnyje aptariama, kokios medžiagos yra prakalbinamos G. Trimako kūrybos procesuose ir apie ką jos prabyla.

Filosofas ir fotografijos tyrinètojas Danielis Rubinsteinas siūlo posthumanistinès fotografijos sąvoką, kuri, anot jo, remiasi ne fotografiniu vaizdu, patriarchaline tapatybės politika ir subjekto-objekto dualizmu, bet plètoja daugialypumą - rizomatini tarpusavyje susijusių fragmentu asambliažą ${ }^{15}$. Remdamasis Gilles’io Deleuze'o ir Felixo Guattari asambliažo ir rizomatinių tinklu koncepcijomis, šis tyrëjas bando iš naujo apsvarstyti reprezentacijos klausimus bei ribas tarp objekto ir subjekto, modelio ir fotografinès kopijos. Mąstant apie fotografiją kaip apie tinklą, iš daugybès fragmentų konstruojamą kolektyvinị asambliažą, šio autoriaus idėjos yra artimos šiame straipsnyje pasitelkiamam požiūriui. Tačiau D. Rubinsteinas tinklo sampratą plètoja analizuodamas sociopolitinių, ekonominių, psichoanalitiniu jègų itakas fotografijai. O šiame tyrime, remiantis B. Latouro tinklaveikos teorija, laikomasi nuostatos, kad parodoje veikia ne tik žmogiški veiksnumai ir intencijos, bet yra aktyvūs ir kiti veikejjai, kurie lygiai taip pat

14 Zygmunt Bauman, Liquid Modernity, Cambridge: Cambridge Polity Press, 2000, p. 104.

15 Daniel Rubinstein, „Posthuman Photography“, in: The Evolution of the Image: Political Action and the Digital Self, eds. Marco Bohr, Basia Sliwinska, New York, London: Routledge, 2018, p. 100-112. 
kaip ir menininkas ar parodos lankytojai jungiasi ị kolektyvinius tinklus ir daro poveikị kūrinių materialumui.

\section{Performatyvūs materialumai}

Turint omenyje, kad viena iš G. Trimako parodos ypatybių yra tai, kad fotografinis dalies kūrinių procesas vyko parodoje, o pats menininkas šių darbų procesą ịvardija kaip performatyvų veiksmą, i šio atvejo analizę kaip prieigą paranku ịtraukti teatrologės Erikos Fischer-Lichte išplètotą performatyvumo estetikos teoriją. Instaliacijos menas dažnai yra kaltinamas teatriškumu, o performatyvumas taip pat yra tapęs gana ịprastu instaliacijos meno elementu, dažniausiai siejamu su žiūrovo judėjimo trajektorijomis ir interakcija su eksponuojamais objektais. Taip pat pažymėtina, kad menininkai Allanas Kaprowas, Claesas Oldenburgas, Robertas Morrisas, Bruce'as Naumanas ir kiti, reikšmingai prisidejję prie instaliacijos meno raidos ankstyvojoje jos stadijoje, 7-8-ajame dešimtmetyje, taip pat imdavosi atlikinèti ir performansus, kurie vèliau neretai papildydavo jų instaliacijas ar skulptūrinius kūrinius.

Performatyvumo sąvoką $1955 \mathrm{~m}$. pristatè britų filosofas Johnas L. Austinas skaitydamas kalbos filosofijos paskaitų ciklą Kaip atlikti veiksmus žodžiais (How to Do Things with Words). Pagrindinis jo teorijos atradimas - kad teiginiais galima ne tik pateikti faktus, dalytis informacija, bet ir atlikti veiksmus. Kaip pavyzdi jis pateikia vedybų arba krikštynu veiksmą, kai pasakydami „taip“ jaunavedžiai įtvirtina naują savo statusą, o krikštijamas naujagimis igauna vardą ${ }^{16}$. Savo knygoje Asthetik das Performativen E. Fischer-Lichte papildo J. L. Austino ir amerikiečių feministès, filosofès Judith Butler jau kultūrinèje filosofijoje išplètotą performatyvumo teoriją ir pritaiko ne tik teatro, bet ir garso ar vizualiesiems menams, tačiau būtent teatras išlieka pagrindinis autorès performatyvusis arkliukas.

Esminė performatyvumo savybė E. Fischer-Lichte teorijoje yra perèjimas nuo kūrinio prie ìvykio. Tokiu būdu ji imasi aktualizuoti dažnai nuvertinamą ar ignoruojamą kūrinio atlikimo veiksmą. Teoretikè išryškina performatyvumo estetikos slinktị nuo diskurso, reikšmès prie kūrinio atlikimo. „Čia „kūrinị“ keičia „ivykis“, „prasmę“ - „medžiagiškumas“, už 
jau sukurtus „tekstus“ svarbesnis tampa „atlikimas“ [...]“17. Tai reiškia, kad veiksmo kūniškumas, medžiagiškumas nustelbia jo ženkliškumą. Medžiagos statusas jau nesutampa su signifikanto statusu, jis tampa autonomiškas ir teigia savo gyvenimą ${ }^{18}$. Kaip pavyzdi ji pateikia Marinos Abramovič performansus, kuriuose menininkė naudoja savo kūną, tačiau ne tik kaip reikšminį ženklą ar simbolị, bet ir kaip medžiagą - kūną ir kraują. Provokatyvūs, kartais ir pavojingi šios menininkès performansai nepalieka materialių artefaktų, bet veikia tiek performansą atliekančią menininkę, tiek žiūrovus, kurie virsta aktyviais performanso dalyviais ir liudytojais, patiriančiais tam tikras emocines, fizines ar kitokias transformacijas.

Aktyvus, kūniškas žiūrovų ir aktorių ìsitraukimas ì performansą yra vienas iš pagrindinių E. Fischer-Lichte teorijos pamatų, kadangi tuomet bent jau kuriam laikui ịvyksta pasikeitimas vaidmenimis, žiūrovai tampa performanso atlikèjais, o menininkai - žiūrovais, nebelieka aiškių ribų tarp subjekto ir objekto, tarp kūrinio kūrèjo ir suvokėjo ${ }^{19}$. Tai autorè ivardija kaip autopoetine grizžtamojo ryšio kilpa - kai aktoriai ir žiūrovai sąveikauja tarpusavyje ir „derasi“ dèl vaidmenų, kurių niekas iki galo negali numatyti, todèl ir atlikimas vyksta tik ji atliekant ${ }^{20}$. Todèl autorè siūlo kalbèti ne apie žiūrovus ir aktorius, o apie skirtingais būdais prie atlikimo prisidedančius bendraautorius.

B. Latouro ir E. Fischer-Lichte teorijas vienija bendras bruožas abu teoretikai bando sugriauti tradicinès subjekto-objekto dichotomijos struktūrą ir visus veikėjus (aktorius, žiūrovus, žmones, gyvūnus, objektus, reiškinius) mato ne kaip pasyvius, bet lygias galimybes veikti turinčius veikèjus, kurių sąveikos lemia kūrinio ar bet kokio kito reiškinio vyksmą. Analizuojant G. Trimako parodą bus pasitelkiama E. Fischer-Lichte performatyvumo teorijos prieiga, bet remiantis B. Latouro idejomis, performatyvumo estetikai reikalingas žmogaus kūniškumas bus pakeičiamas objektų materialumu, t. y. ì svarstymų lauką ittraukiant ne tik žmogaus, bet ir nežmogaus kūnus, aplinkos bei gamtos veiksnumus. 


\section{Gintauto Trimako paroda kaip performatyvių veikèjų tinklas}

Keturiose galerijos erdvèse fotomenininkas eksponavo kūrinių seriją Atsakymas. Parodos kūrinius galima suskirstyti ị dvi kategorijas. Vieni jų buvo jau užbaigti, o kitų fotografiniai procesai vyko parodoje; būtent pastaroji kūriniu grupė yra svarbiausia šio straipsnio svarstymo ašis. Analizuojami kūriniai atlikti naudojantis ankstyvosiomis fotografinėmis technikomis. Viena jų - šviesos atspaudas (lumen print), kurio atradejjas mokslininkas Williamas Henry Foxas Talbotas. Šio metodo esmė, kad ant fotografinio popieriaus esantis sidabras reaguoja i šviesą ir ima tamsèti. Ryškinant atspaudą apšviestas sidabras lieka ant popieriaus, o neapšviestasis - nuplaunamas. Kiti kūriniai atlikti cianotipijos (cyanotype) technika, kurią 1842 m. išrado britų mokslininkas ir astronomas Johnas Herschelis. Ši technika buvo itin populiari XX a. kaip sąlygiškai nebrangus ir paprastas būdas fotografijoms, brèžiniams, žemèlapiams ir planams kopijuoti. Kaip tik dèl cianotipijai būdingos monochrominès mèlynos spalvos techniniai brèžiniai igijo bendrinị blueprint (mèlynasis atspaudas) pavadinimą. Šioje technikoje naudojamas cheminių medžiagų natrio, geležies ir cianido junginys reaguoja ị šviesą, ir gaunami šviesiai ar tamsiai mėlynos spalvos atspaudai. Beje, abi technikos dažnai buvo pasitelkiamos biologijos, botanikos ir kitų mokslų srityse atliekant augalų bei kitų objektų fotogramas.

G. Trimako parodą taip pat galima matyti kaip atliekamą atspaudą, fotogramą. Minètuose kūriniuose atspaustas ir užfiksuotas jau ne vienas konkretus objektas ar ju grupė, bet veikiau visas aplinkos kolektyvas, o jis taip pat atskleidžia fotografijos istorijai svarbius tarpdisciplininius aspektus. Menininkas pasitelkdamas senąsias fotografines technikas atlieka anachronišką judesį, kadangi cianotipija ar sidabro atspaudas buvo tikslingai naudojami gamtos mokslų, meno, architektūros ir kitose disciplinose. Žvilgsnis ị camera-less fotografijas kaip ị kolektyvinị aplinkos, kūrinio paviršiaus ir menininko rezultatą - aktyvių veikejjų tinklą - aktualizuoja ir jungia šias disciplinas, kurios buvo pasitelkiamos dar XIX a. bei vèliau plètojant fotografijos techniką ir meną. Svarstant apie šias technikas reikia žinoti, kad fotografija plètojosi ir darè itaką kitoms disciplinoms, kaip ir pastarosios - fotografijai. Tačiau analizuojant šių kūrinių materialumą reikia 
atsižvelgti ne tik i meno istoriją ir diskursą, bet lygiai taip pat atkreipti dėmesị $i$ fizikos dėsnius, chemines reakcijas ar aplinkoje esančias architektūrines detales. Šiuose kūriniuose ant popieriaus ịsirèžia daugybè ịvairių sluoksnių - abstrakčiose mèlynos spalvos juostelèse matyti architektūrinių, biologinių, cheminių, fizikinių, meninių, dokumentinių ir fotografinių disciplinų bruožų. Visi jie galėtų būti pasitelkiami aprašant ir nagrinèjant šiuos kūrinius. Tai rodo, kad kalbant apie G. Trimako kūrybą nereikètų skubèti uždaryti juos vienoje ar dviejose disciplinose, diskursuose, bet veikiau taip pat žvelgti kaip i hibridus, kuriuose poetiškai igyvendinamos B. Latouro idejjos apie vientisą gamtos ir kultūros audinị, kuris ši kartą užmezgamas ant šių kūrinių paviršiaus, ịsirašo ị spalvų kodą.

Atkreipus dèmesi ị fotografo kūrinių tarpdiscipliniškumą, galima pažvelgti, kaip ịvairūs veikẻjai veikia parodos erdvėje. Kaip teigia E. FischerLichte, atlikimo erdvę reikia suvokti kaip performatyvią. ,Ją keičia bet koks žmonių, objektų, šviesos judejjimas, bet koks garsų skambesys. Ji nẻra pastovi, ji nuolat kinta. Performatyvi erdvė kuria atlikimo erdviškumą, jis suvokiamas šios erdvės nustatytomis sąlygomis“"21. Dalị kūrinių vienijantis performatyvus veiksmas šiame straipsnyje leidžia ị juos pažvelgti kaip ị vientisą kūrinį - erdvę, kurioje vykstanti aplinkos choreografija veikia ne tik žiūrovą, bet ir kūrinius. Parodoje eksponuojami darbai puikiai atitinka vieną iš pagrindinių naujojo materializmo teiginių, kad materija nèra pasyvi ir inertiška įvairūs žmogiški ir nežmogiški objektai yra aktyvūs veikejjai, kurie jungiasi i kolektyvus, mezga tarpusavio tinklus ir prisideda prie kūrinio atlikimo.

Eksponuojami kūriniai, taip pat kaip ir aplink esantys objektai bei aplinka, tampa aktyviais visą parodą trunkančio performatyvaus veiksmo veikẻjais. Per langus i parodos erdvę patenkanti šviesa yra viena iš pagrindinių tokių veikejjų. Dèl ant popieriaus padengtų cheminių medžiagų savybių elektromagnetiniai spinduliai nuolat veikia atliekamų kūrinių paviršių, per laiką leidžia jam keisti spalvą ir pamažu iš šviesiai žalios natrio geležies junginys virsta mèlynu. Kaip veikejjai šiame procese gali būti laikomi lokalūs, visiškai šalia esantys objektai - pastato interjero detalès, šviestuvai, langai, lankytojai, lauke esantys medžiai bei aplinkiniai pastatai. Kaip veiksnumą galima įžvelgti net tokias aplinkybes, kaip galerijos darbo laikas, nuo kurio 
priklauso, ir kada ijungiamos šviesos ar priimami lankytojai, jau nekalbant apie menininko priimtus sprendimus, kur ir kaip eksponuoti ir parengti kūrinius fotografiniam procesui vykti. Visi šie veiksniai jungiasi į šviesos spindulių veikiamą tinklą ir buvimu aplink kūrinị atlieka savo vaidmeni - lygiai taip pat veikia šviesos judejimą, meta šešèli ir taip prisideda prie kūrinio atlikimo. Ši veikèjų tinklą lygiai taip pat galima praplèsti iki kur kas tolimesnių veikejjų, pavyzdžiui, kosminių objektų, kaip kad Žemè, kurios judèjimas veikia gamtos procesus - metų laikus, dienų trukmę, klimatą ir pan. Kodèl sustojus čia? Žvelgti galima ir dar toliau, ir Žemė yra priklausoma nuo kitų dangaus kūnų išsidėstymo, iš kurių mums svarbiausia Saulė - dèl jos skleidžiamų spindulių šis procesas išvis įmanomas. Šiuose procesuose kūrinių paviršius reaguoja ị aplinką ir jos pokyčius, būtent jis tampa esmine kūrinio medžiaga, nustelbiančia savo ženkliškumą. Kaip knygoje Gamtos pieštukas rašè F. Talbotas, „šviesa ten, kur egzistuoja, gali virsti veiksmu, o tam tikromis aplinkybėmis tokiu veiksmu, kuris gali sukelti materialiu kūnų pokyčius " ${ }^{\text {"22. }}$ Kaip ir šviesa, kiekvienas objektas, savo ruožtu, užstojantis šviesos šaltinį, metantis šešèli ant kūrinių paviršiaus, taip pat prisideda prie kūrinio vyksmo, jo formavimosi, bet ir palieka tiesioginį pėdsaką ant jų.

Itin akivaizdžiai visų veikẻjų dalyvavimas atliekant kūrinị išryškèja menininko eksponuojamose knygose [2 il.]. Prieš parodos atidarymą menininkas kiekviename šių knygų puslapyje „rašalu“, sudarytu iš natrio, geležies ir cianido junginio, nubrèžè po juostą. Užvertus knygą, šios juostelès liktų žalsvos spalvos, tačiau atėję parodos lankytojai gali vartyti šias fotografines knygas; atverstą knygą palikti ar po kelių sekundžiu užversti. Atvertus kiti aplinkos veikejjai iškart imasi savo darbo, o jei knyga užversta, jos krašteliuose vis tiek galima pastebèti jau be žmogaus pagalbos tarp puslapiu ịsispraudusios šviesos pėdsakus, nes puslapių kraštai visuomet tamsesni ir ryškesni už viduryje esančius linijų fragmentus. Žiūrovas čia tampa sąlyginiu veiksmo iniciatoriumi, tačiau su visais aplinkos kolektyvais - ir jo atlikejju. Tad su šiais kūriniais ìvyksta E. Fischer-Lichte performatyvumo estetikoje įvardyta autopoetine grižztamojo ryšio kilpa, kai visi dalyviai sąveikauja, tačiau nė vienas negali visiškai suplanuoti ir kontroliuoti, taigi kurti atlikimo, niekam nepavyksta juo disponuoti ${ }^{23}$.

22 William Henry Fox Talbot, The Pencil of Nature, London: Longman, Brown, Green \& Longmans, 1844, p. 4.

23 Erika Fischer-Lichte, op. cit., p. 81. 


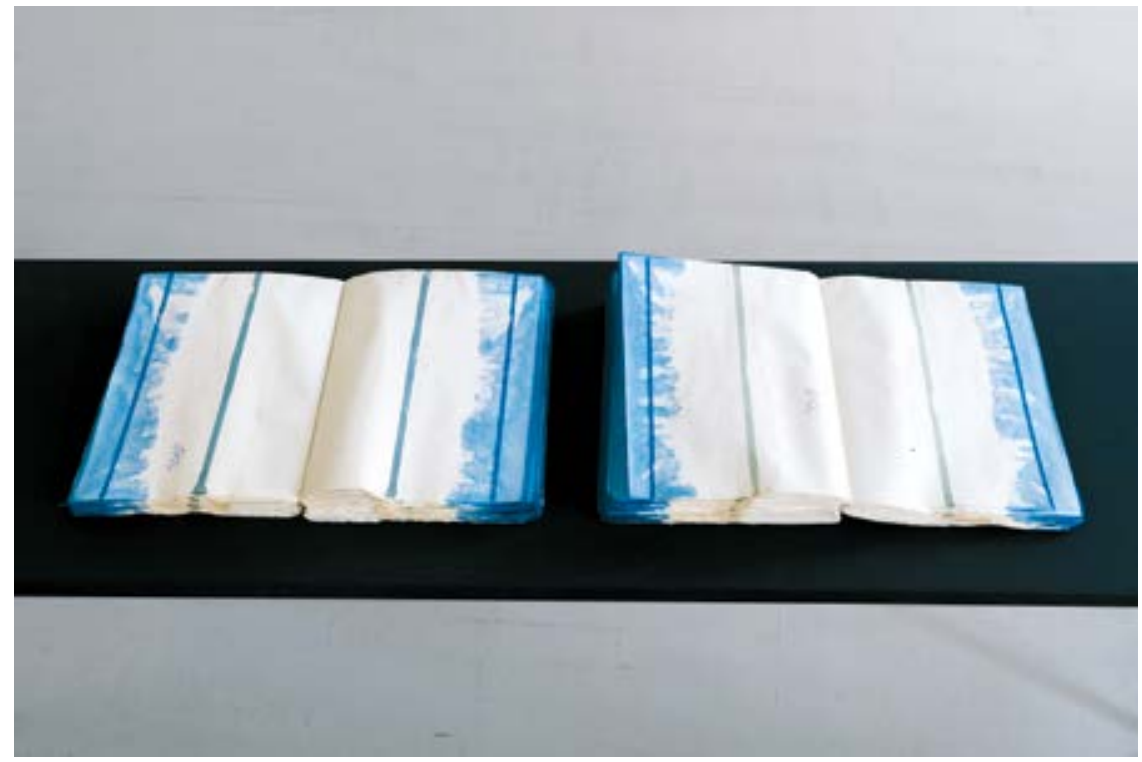

2.

Gintautas Trimakas, iš ciklo Atsakymas parodos fragmentas, 2018, galerija „Vartai“, Lauryno Skeisgielos nuotrauka, LATGA, Vilnius 2021
Gintautas Trimakas, from the series Answer, installation view, 2018, LATGA, Vilnius 2021

Kalbėdama apie teatrą E. Fischer-Lichte teigia, kad žiūrovų ir aktorių pasikeitimą vaidmenimis galima suprasti kaip:

galios praradimo ir igijimo procesą [...]. Menininkai atsižada galios būti vieninteliais spektaklio kūrẻjais ir skelbia esą pasirengę autoryste ir apibrèžimo galia dalytis - nors ir skirtingu mastu - su žiūrovais. ${ }^{24}$

Šioje parodoje iž̌velgiama analogiška situacija, kaip ir projekte Miestas kitaip: menininką galima vertinti veikiau kaip koncepcijos autoriu, paruošiantị erdvę ir objektus performatyviam veiksmui atlikti. Šioje situacijoje jis kaip režisierius surenka veikejjus, parengia scenografiją ir numato veikėjų atlikimo galimybes, bet atlikimą palieka atsitiktinumui, veikejju sąveikos rezultatui, kad ir koks jis būtų. Negana to, turint omenyje, kad G. Trimako darbai pasižymi abstraktumu - nèra konkretaus vaizdinio, jam 
pavyksta bent iš dalies atsiriboti nuo konkrečios fotografo perspektyvos, kuri taip pat sukuria subjektyvią žmogaus poziciją, savitą žvilgsni, kurị čia pakeičia fotografinis procesas ir jame dalyvaujantys veikejjai. Panašiai fotografijos objektyvumą pasaulio atžvilgiu pastebi ir kita Lietuvos fotografè Akvilè Anglickaitè:

fotografijai būdingos savybès „sąžiningai“ atvaizduoti viską, kas atsiduria priešais fotoaparato objektyvą, ir dèl to, kad objektai ar aplinka „patys save piešia“ ant šviesai jautraus paviršiaus, fotografas užfiksuoja tai, ko jis net nesitiki užfiksuoti. ${ }^{25}$

G. Trimako parodoje neveikia ịprasti subjekto-objekto, stebėtojo ir stebimojo ryšiai. „Kiekvienu atveju deramasi dèl procesų, kuriuos galima būtų apibūdinti kaip naujus santykius tarp bendruomenės narių, nustatančių demokratizacijos procesus. “26 Užuot kalbėję tik apie tai, kaip meno kūrinys - objektas veikia jị stebinti subjektą, materialiajame lygmenyje čia vyksta ir atvirkščias veiksmas. Dèl fotografinių procesų eksponuojami kūriniai taip pat reaguoja, „stebi“ subjektą bei kitus objektus, būtent ant jų paviršiaus ịvyksta transformacija kaip reakcija ị aplinkos veikėjus. Subjekto ir objekto kategorijos igauna lygiavertiškuma, ịvyksta tam tikras demokratizacijos procesas, kai subjekto veiksnumas yra toks pat, kaip bet kokiu aplinkos faktorių, sąveikaujančių su šiuo objektu. Todèl skirtis tarp objekto ir subjekto esmiškai tampa nebeaktuali, jie galètų būti laikomi objektais tarp objektų arba subjektais tarp subjektų. Toks veiksmas atitinka posthumanistinès etikos principą, kai žmogus nelaikomas viską kontroliuojančia, aukščiau visų esinių esančia figūra. Šiuo atveju tiek kūrèjas, tiek lankytojai yra bendro kolektyvo dalis, heterogeniški veikèjai, kurių veiksnumas yra tiek pat priklausomas nuo jų, kiek ir nuo kitų veikejjų.

Priešingai nei E. Fischer-Lichte teorijoje, G. Trimako kūriniai neapsiriboja tik atlikimu, jis palieka realų artefaktą, ịvykusio ịvykio liudininką. Šiuo atžvilgiu fotografo parodos performatyvumas yra kiek artimesnis J. L. Austino ar J. Butler performatyvumo sąvokai, kurioje performatyvūs aktai nuolat kuria tapatybę - kaip kūnišką ir socialinę tikrovę ${ }^{27}$. Parodoje

25 Akvilè Anglickaitè, Netikrumas šiuolaikinejje kultūroje. Fotografijos fenomenas: Meno projektas, Vilnius: Vilniaus dailès akademija, 2017, p. 82.

26 Erika Fischer-Lichte, op. cit., p. 81.

27 Ibid., p. 43. 
veikejjai, jungdamiesi ị veikẻjų tinklus, keičia kūrinio „kūną“. Kūniškumą konvertavus ị cheminių medžiagų reakciją i šviesą, matoma, kaip performatyvūs veikẻjų veiksmai visos parodos metu veikia fotografinius procesus, patys savo ruožtu tampa aktyviais atlikimo veikejjais, prisidedančiais prie kūrinių steigimo, jų materializavimosi. Jiems nesąveikaujant kūriniai iggautụ kiek kitoki vaizdą, o kai kuriais atvejais galbūt taip ir liktų nepasikeitę. Tačiau kūriniai neturètų būti laikomi pasyviais, tik kažkieno kito veikiamais objektais. Jie yra vieni iš šios sąveikos veikeju, turinčių tam tikrus veiksnumus, kurie ši kartą leidžia pastebèti viso veikejjų tinklo susietumą. Tad menininkas šiuose darbuose sukuria erdvę, kurioje susipina ir užsifiksuoja tiek kultūriniai, tiek gamtiniai dèmenys, o kūrinio atlikimas tampa šiu sąveikų rezultatu. Jị galima priskirti meno paradigmai, bet lygiai taip pat ịtraukiantị ir fizikos, chemijos bei kitų disciplinų žinių. Šie kūriniai ne atskiria, bet jungia įvairius dèmenis ir demonstruoja, kad hibridiškumas yra natūrali būsena, svarstymams atverianti daugybę dažnai nepaisomų kūrinio atlikimo ir jo gyvavimo aspektų.

\section{Išvados}

Straipsnyje apžvelgtos Bruno Latouro tinklaveikos ir Erikos Fischer-Lichte performatyvumo teorijos, kurios pasitelktos kaip metodinė prieiga aptarti fotomenininko Gintauto Trimako parodos Atsakymas kūrinius, kurie straipsnyje traktuojami kaip instaliacijos meno objektai.

Menininko pasirinkimas parodoje eksponuoti ne tik baigtinius, bet ir erdvėje atliekamus kūrinius leido juos apžvelgti kaip žmogiškų ir nežmogiškų veiksnumų tinklą. Parodoje vykstant fotografiniams procesams ịvairaus mastelio veikejjai, pradedant aplinkoje esančiais elementais, kaip kad ekspozicinė erdvè, lankytojai, už galerijos langų esantys medžiai ir pastatai, o baigiant Saulès skleidžiamais elektromagnetiniais spinduliais yra aktyvūs veikejai kūrinio atlikimo procese. Ant kūrinių paviršiaus esantiems cheminiams junginiams reaguojant $\mathfrak{i}$ šviesą, bet kokie gamtos ar aplinkos veiksnumai daro tam tikrą poveiki galutiniam kūrinio rezultatui. Tai laikoma performatyviu veiksmu, kai kūrinys yra formuojamas, o tai atliekantị performatyvių veikejjų tinklą galima laikyti sąlyginiais kūrinio atlikimo bendraautoriais. 
Pastebèta, kad parodoje pranyksta aiškios ribos tarp dualistiniu gamtos-kultūros ir objekto-subjekto struktūrų. Šioje parodoje visi veikejjai igauna lygiavertị statusą ir prie kūrinio atlikimo gali prisidèti tiek žmogiški, tiek nežmogiški veikejjai. Subjekto ir objekto pozicijos praranda savo aktualumą pripažinus, kad objektai nèra pasyvūs, bet taip pat, kaip ir subjektas, gali reaguoti ị kitus aplink esančius objektus bei patys būti aktyviais performatyvaus veiksmo veikèjais.

Gauta 20201120 


\section{Literatūra}

Anglickaitė Akvilè, Netikrumas šiuolaikinèje kultūroje. Fotografijos fenomenas: Meno projektas, Vilnius: Vilniaus dailès akademija, 2017.

Bauman Zygmunt, Liquid Modernity, Cambridge: Cambridge Polity Press, 2000.

Fischer-Lichte Erika, Performatyvumo estetika, vertè Austėja Merkevičiūtè, Vilnius: Menų spaustuvè, 2013.

Foster Hal, „The Un/making of Sculpture“, in: Richard Serra: Sculpture 1985-98, eds. Ferguson et al., Gottingen and Los Angeles, 1998, p. 13-36.

Latour Bruno, Mes niekada nebuvome modernüs: simetrinès antropologijos esé, iš prancūzų kalbos vertè Natalija Vyšniauskaitè, Vilnius: Homo liber, 2004.

Latour Bruno, Reassembling the Social: An Introduction to Actor-Network-Theory, Oxford: Oxford University Press, 2007.

Lukys Alvydas, „Dabartis tęsiasi: Gintauto Trimako Fotokosmosas“, in: Gintautas Trimakas, [fotografijų albumas], sud. Gytis Skudžinskas, Gintautas Trimakas, Agnė Narušytè, Vilnius: Lietuvos fotomenininkų sajungos fotografijos fondas, 2016, p. 184-185.

Narušytė Agnè, „Fotografijos fenomenologija pagal Gintautą Trimaką“, in: Gintautas Trimakas, [fotografiju albumas], sud. Gytis Skudžinskas, Gintautas Trimakas, Agnė Narušytè, Vilnius: Lietuvos fotomenininkų sajungos fotografijos fondas, 2016, p. 15-18.

Oliveira Nicolas de, Oxley Nicola, Petry Michael, Installation Art In The New Millennium, London: Thames and Hudson, 2003.

Rubinstein Daniel, „Posthuman Photography“, in: The Evolution of The Image: Political Action and the Digital Self, eds. Marco Bohr, Basia Sliwinska, New York, London: Routledge, 2018, p. 100-112.

Talbot William Henry Fox, The Pencil of Nature, London: Longman, Brown, Green \& Longmans, 1844.
Trimakas Gintautas, „Apie miestą kitaip“, in: Idem, Miestas kitaip = City. A Different Angle. Vilnius \} Köln \} Klaipèda \} Lviv \}, sud. Margarita Matulytè, Kaunas: Kitos knygos, 2009, puslapiai nenurodyti.

Trimakas Gintautas, „Lumen: Parodos anotacija“, [interaktyvus], in: artnews.lt, [žiūrèta 2020-08-22], https://artnews.lt/gintauto-trimako-paroda-lumen-galerijoje-meno-parkas-diuseldorfe-56360.

Trimakas $\{$ Gintautas $\}$, Miestas kitaip $=$ City . A Different Angle. Vilnius \} Köln \} Klaipėda \} Lviv \}, sud. Margarita Matulytè, Kaunas: Kitos knygos, 2009, puslapiai nenurodyti.

Valatkevičius Jonas, „Trimakas. Ten ir čia. Dabar ir kažkada“, in: \{Gintautas\} Trimakas, Miestas kitaip $=$ City. A Different Angle. Vilnius \} Köln \} Klaipėda \} Lviv \}, sud. Margarita Matulytė, Kaunas: Kitos knygos, 2009, puslapiai nenurodyti.

Žukauskaitè Audronè, „Pratarme““, in: Athena, 2019, Nr. 14, p. 8-9.
99 2020

Acta Academiae Artium Vilnensis 


\title{
Summary
}

\section{Performative Networks of Actors in the Works of Gintautas Trimakas}

\author{
Marius Armonas
}

Keywords: photography, installation, actor-network theory, performativity, posthumanism.

The present article revisits Bruno Latour's Actor-Network theory, as well as Erika Fischer-Lichte's theory of performative aesthetics, which are employed as a methodical approach to review the works of Lithuanian photographer, photographic artist Gintautas Trimakas, in his exhibition Answer.

In the exhibition, the artist chose to present a series of works whose photographic processes took place in the gallery space itself. This decision opened new possibilities to consider the exhibition as a performative action carried out by various networks of actors, starting from local, surrounding objects, such as the space itself, the visitors and architectural elements, and ending with electromagnetic waves generated by the Sun or the rotation of the Earth. All these factors played a role in creating photographic images in the camera-less technique, capturing the light throughout the exhibition. Hence, it is proposed that these actors should be considered co-authors of the work.

It is noted that the traditional dual structures of nature / culture, and object / subject have faded away. All the actors in this exhibition have received an equal status; therefore, human as well as non-human agents are recognized to have participated in this performative action. Thus, the visuality of the work should be considered a result of collective effort. Moreover, the positions of a subject and an object have also lost their relevance, since the objects of the exhibition are no longer seen as passive; just like the subjects, they are able to react to the surroundings and be active performers of the work. 